\title{
Gender Differences in Saving Behavior and its Determinants: Patron from Pakistan
}

\author{
Taqadus Bashir ${ }^{1}$, Ali Hassan ${ }^{2}$, Shahzad Nasir ${ }^{3}$ Arslan Baber ${ }^{4,}$ \\ Waqas Shahid \\ (Assistant Professor, Department of Management Sciences, University of Gujrat, Pakistan) \\ (MS Scholar, Department of Management Sciences, University of Gujrat, Pakistan) ${ }^{2}$ \\ (MS Scholar, Department of Management Sciences, University of Gujrat, Pakistan) ${ }^{3}$ \\ (MS Scholar, Department of Management Sciences, University of Gujrat, Pakistan) ${ }^{4}$ \\ (MS Scholar, Department of Management Sciences, University of Gujrat, Pakistan $)^{5}$
}

\begin{abstract}
Pakistan is developing country and the areas selected from Punjab province are in initial stages of development. Saving behaviors of these areas are significantly different from other areas. Saving behaviors among genders of developing economy of Pakistan are different from developed economies. The fundamental aim of conducting this research is evaluating gender dissimilarities in saving behavior and determinants of saving behavior among males and females of Punjab, Pakistan. Sample size of this study includes males and females. Total 400 questionnaires were selected for study which includes 124 responses of females and 276 for males. Non-parametric test of chi-square for gender dissimilarities in their saving behaviors and linear regression for the determinants of saving behavior applied in study. Findings of study show that males and females have significantly different saving behaviors. Females save mostly and more for short term needs as compare males while males also save for medium and long term needs. Both males and females have significantly different impacts of determinants of saving on saving behavior except from education, work status, own home, risk tolerance level and medical expenses. The originality of this study is that it is first research work in Punjab, Pakistan on this topic especially in these four cities selected for analysis.
\end{abstract}

Keywords: Gender Differences, Saving Behavior, Determinants of Savings, Consumption Patterns Saving Preferences,

\section{Introduction}

Saving is an important economic factor and saving habits play important role in the economic system of developing economies. Many studies have been conducted to measure the saving behaviors of individuals as well as the determinants of saving of different economies. These studies have revealed that the economic welfare and fiscal behavior of male and female differ meaningfully. Females have less income as compare to males. Investigators and business experts have observed that women invest huge where certainty of outcomes higher and have risk aversion behavior as compare to males [1,2]. Investment analyst and advisors feel difficulty while guiding them for investments as they are characterized by low level of income, more risk aversion and low level of saving behaviors. As to much research has been conducted on gender dissimilarities in earnings, variations in stock performance and capital, but very little research is available as on what type of factors effecting the saving patterns of both genders.

There are very few studies available to observe whether there are gender differences in saving at the household level, in spite of saving as emerging issue in respect to the security of households. Sunden and Surrette [6] explore that females have fewer well-defined savings strategies, while Agnew [7] findings were opposite from this. Many differences have been observed about the holding of wealth and investment portfolio decisions among male and females may repeat basic differences in elements related with saving behaviors, so it is essential and necessary to recognize these differences.

Factors inducing the saving patterns suggested the differences in welfare among mature as well immature genders. This paper broadens the works by examining disparity in the saving habits of both genders. Factors considered for saving patterns by different researchers in past will be linked to analyze the dissimilarities in genders for these important factors.

Huge gender disparity has been analyzed for human welfare, in different economies. This study is conducted to investigate dissimilarities among genders for saving habits to comprehend that what type of factors are responsible for different behavior of savings among males and females in the developing economy of Pakistan, especially in Punjab. This study is quite different in comparison to studies conducted in past by other researcher as its focus on dissimilarities of both genders for habits of saving money. It will also analyze dissimilarities on the basis of marital status but household are headed mostly by males. Focus of many 
researcher studies in past was on the gender differences in terms of income and causes of lower income. Research work on general saving behavior of males and females is available but very few and most importantly there is few research on the developing economy like Pakistan. Most of the researchers have analyzed direct impact of higher income level on saving habits. Our study will also consider other factors that have impact on saving hobbits of both genders.

Saving behavior differ from country to country and from area to area. In Pakistan, people also have different saving patterns according to their province and city in which they live. It is important to identify these dissimilarities among genders in developing economies like Pakistan. Most of the studies conducted in developed economies and the results of these studies can not apply in developing economies. There are many differences in terms of economic conditions, socialization, political and religious factors etc. that effects directly to consumption as well as saving habits. The aim of the study is also to identify those factors.

\section{Review Of Literature}

Many studies have explored that financial manner of both genders and the economic well-being having no similarities between them. In these gender differences both male and females shows different behavior. Women have very low amount of wealth and their earning is significantly low as compared to men. Recently, women spend more as compared to men and their age is also five more years then male [19, 23].Sung \& Hanna [22] found that the men who were not married were high risk tolerant than single women, where Suden \& Surrette [6] found that women who were single, were not more risk tolerant than men. Males hold more stocks and hold less certificates or license of deposits as compared with females [15]. Bajitelsmit et al. [1,2] showed that men did not received traditional advices, their view changed with time and focuses on new market trends, where women received conservative investment information's than men. Bajutelsmit et al. [2] found that men were less risk averse than women.

Demographic characteristics were included in this research. Many studies show that, there exist a relationship between saving and the demographic variables. Many studies also showed the positive relationship between saving and age. This positive relation between saving rates and age is recommended by The Life-cycle model. Burney and khan [13] found that saving shows the positive trend with age, as age increases to a certain limit, savings increases. The data was collected from the household integrated assessment 1988-99.OLS method was adopted to choose the data of 5374 urban families and 8933 rural families. The result of their study shown that employment status, sex of household head, age and income have positive effect on saving behavior.

Kelley [11] examined the influence of the level of education on household saving. Burney and Khan [13] showed in their study that a person who have high level education, they have relatively high consumptions and on the other hand the households who were educated, there earning is more. Generally all the decisions were taken by the head of the households about saving and the education of households head appear to be relevant variable. In our study, the level of education is described by the five categories i.e. under matric , matric, under graduate, graduate and post graduate. The working status of the head of the household is attention able because it is the main source to study the differences in saving behavior in developing countries of household.

The head of the household also have impact on the saving of households. Saving patterns of households having high level education and low level education are different as households having technical education or professional degree are save less than those of the house hold having high school diploma. It is discovered that white respondent's household save more than those of the Hispanic or black households and black households are founded to save less than those of the white respondents [10].

In Indonesia, results of study showed that the saving habits of self-employed respondents are high [11]. Morris and Perry [9] found that those people who have higher incomes were considering themselves responsible for managing the financial behaviors, such as saving money. People having their own home are more likely to save then the people living in rental houses.

According to Gneezy and Croson [14], a number of studies in sociology and psychology indicated that women shows risk aversion behavior than men. Brinig [29] conducted a study upon male and female respondents having different ages and indicated that level of risk taking is high at the age of 30 and concluded that behavior of men is more risk taking in that period in which they are committed to their family and women shows risk averse behavior in the years of child-bearing.

All these findings that are mentioned above proves a powerful relationship in between the gender differences of male and female and their preferable level of risk. On the other side some experts have opposite results of their studies that the genders have no effect on saving behavior. For example, gender difference has no impact in the dollar holdings of stocks [15]. Su and DeVaney [18] founded that men and women were similar in knowledge of retirement paining. There is no risk in propensity of taking risk between men and women entrepreneurs [19]. 
Findings related to the existence of wealth gap between male and female headed households are mixed. In single male and female headed households there is no significant difference of wealth gap despite the fact that female households being likely to contain children [8]. Many researchers have suggested several possible reasons for wealth gap between male and female headed households [20, 24, 25]. Women typically have lower earning than man and also have lower lifetime so they create lower total wealth. Women also completed fewer year of education than man which also affect their earnings [19].The attachment to the labor force also different between men and women that could also lead to the observed differences in financial behavior of men and women [28].

Any difference in wealth of women result from their lower participation in labor force, women tend to have part time work arrangements and most of the women have diversified work history due to the rearing and bearing of their child and they also tend to have change their job frequently [26]. In addition a persistent gender gap in earnings leads the women to have less wealth even the saving rates constant [20, 24, 25 ]. Evidence also suggests that gender difference in information processing play a role in having different financial strategies [16]. Lusardi and Mitchell [21] found that due to the difference between financial knowledge that men have more financial knowledge than women effect both saving and portfolio choices of women.

Lupton and Smith [17] found that many aspects of the saving behavior were left unexplained even after controlling the socio economic and demographic characteristics of households. In his capital theory, Becker [27] he stated that women rationally chose to invest less than men in human capital including education, on job training affecting women's employment opportunities, skills and abilities to accumulate the wealth. The choices that women make are different than men due to greater family responsibilities with the gender division of labor within family resulting women taking the responsibility of child care and household work [1, 2].

Researcher has shown that due to the difference between preferences of men and women affecting the labor and consumption decision of both men and women that they make [14]. Women have been shown to invest differently than the men but through this we can only little known how general saving behavior differ between men and women.

According to Perry and Morris [9], due to the difference in socialization of men and women during childhood they are different in financial matters. Furthermore, the findings show that financial knowledge was the first and strongest determinant of savings behavior among male and female.

\subsection{Sample Size}

\section{Methodology}

Pakistan is a developing country and its province Punjab is the largest one. Punjab is the largest province in the terms of population as well as the largest contributor in the development of Pakistan. The sample size of this study consists of four important cities of Punjab as Gujrat, Gujranwala, Wazirabad and Kharian. Primary data collection method was used and questionnaires were filled up from more than 400 households of these cities but only 400 questioners were completed and selected for this study. Some of the questionnaires were incomplete and rejected. Respondents of questionnaires include both male and female. The total numbers of males were 276 with $69 \%$ representation in total sample size of the study while numbers of female respondents were 124 with $31 \%$ representation. Another important category of questionnaires to measure the differences among male and females was the marital status.

There were two important reasons for selecting four cities as sample of study. First, most of the households are male headed even when both the genders are earners to fulfill financial needs. Second reason was that in these areas of Punjab there is a concept of one or two members are earners for their families while the others are dependent on them for their consumption needs. So it was important to check the saving behaviors of males and females under different scenarios, economic conditions, social conditions and their work status in society as well as in their families.

\subsection{Variables of Study}

Decision making process about the spending patterns affects the saving behaviors of individuals. Individual save a sum of money regularly [30,31] to fulfill their short term, long term and medium term needs. In this study, saving behavior was measured in terms short term, long term and medium term saving behaviors among genders. Data about saving behavior was collected through a question in which respondents selected one response from three responses short term saving, medium term saving and long term saving.

Saving behavior of individuals is effected by many factors. Independent variables of the study were income, age, risk tolerance, preferences, and consumption needs [3]. Income level was classified into five ranges as >10000, 10000-20000, 20000-30000, 30000-40000 and 40000>. Categories for age were 4 as 15-25 years old, 26-35 years old, 36-45 years old and 45> years old. Risk tolerance level of individual households was measured by creating dummy variables as low, average and above risk. Saving preferences were measured trough five categories: $1-10 \%, 11-20 \%, 21-30 \%, 31-40 \%$ and $40 \%>$. For the purpose of measuring consumption 
pattern four dummy variables were created: household expenses, medical expenses, education expenses and miscellaneous expenses and each dummy variable was measured on scale as 1-10\%, 11-20\%,21-30\%,31-40\% and 40\%>. Socioeconomic variables were used as control variables in this study. Socioeconomic characteristics of province, education, and income source and work status were used as control variables [3].

\subsection{Conceptual Framework}

The conceptual frame work of the study according is given in figure 1 . This frame work shows the impact of independent variables (income, age, risk tolerance, preferences, and consumption needs) and control variables (province, education, and income source and work status) on dependent variable of saving behavior on male and females. The independent and control variables have been considered as the determinants of saving.

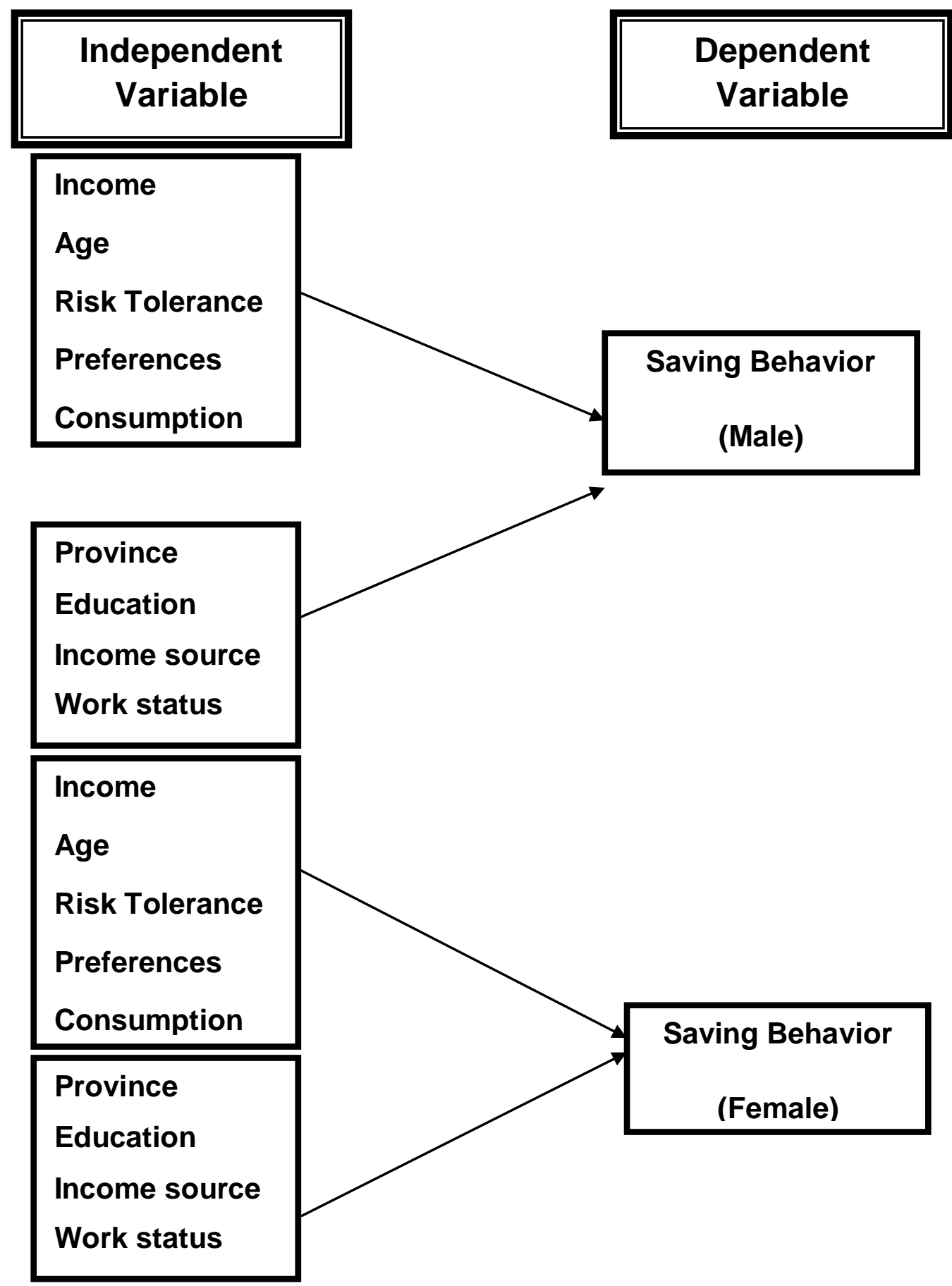

Figure 1 


\subsection{Empirical Model}

The regression analysis will be applied by using two equations, first equation for males as model 1 and second equation for females as model 2 to check the impact of determinants on saving behavior for both genders.

Model 1

Saving Behavior $=\beta 0+\beta 1$ Income $+\beta 2$ Age $+\beta 3$ Preferences $+\beta 4$ Risk $+\beta 5$ Consumption $+\beta 6$ Province + $\beta 7$ Education $+\beta 8$ Income source $+\beta 9$ Status $+\mathrm{e}$

Model 2

Saving Behavior $=\beta 0+\beta 1$ Income $+\beta 2$ Age $+\beta 3$ Preferences $+\beta 4$ Risk $+\beta 5$ Consumption $+\beta 6$ Province + $\beta 7$ Education $+\beta 8$ Income source $+\beta 9$ Status $+\mathrm{e}$

$\mathrm{e}=$ Stands for error term

\subsection{Descriptive Analysis}

\section{Results And Analysis}

Total sample size for analysis included 400 households, with $69 \%$ males (276 respondents) and $31 \%$ females (124 respondents). Descriptive statistics of total sample is given in Table 1.1 while descriptive analyses of male as well as female are given in Table 1.2 and Table 1.3 respectively. There is significant differences in age as almost 50\% males have 26-35 years old age as compare to females with $64 \%$ (26-35 years old age) while $32 \%$ females have 15-25 years old age as compare to $17 \%$ males with same age pattern. Almost both genders males and females belong to Punjab and a little difference in the terms belongs to provinces as $93 \%$ females and $81 \%$ males belong to Punjab. Educational background is different of both genders from each other. Higher education of males is higher as $50 \%$ have post graduation as compare to $32 \%$ of females while on the other hand overall educational level of females is higher as compare to males because no females have education less than under graduation and graduation level of females (58\%) is also higher as compare to males (37\%).

Income level of males is higher with $42 \%$ males have more than 40,000 rupees as compare to females with $12 \%$ having more than 40,000 while the income source of almost $92 \%$ females is salary but only $50 \%$ males are salaried while remaining 50\% have other sources of income includes rent of property, investment and most common is foreign remittances $(26 \%)$. Almost same difference exist in the categorization of work status of both genders as $95 \%$ females are government employed as compare to 53\% males while $42 \%$ males are self employed. Saving preference are also different males tried to save more income as compare to females. Descriptive statistics shows that almost $45 \%$ males save $20-40 \%$ of their income while only $20 \%$ females save $20-40 \%$ of their income. It is also observed that females are more risk aversion (42\%) as compare to males $(31 \%)$.

Table 1.1 Characteristics of all Households

\begin{tabular}{|c|c|c|c|c|c|}
\hline Gender & Male & Female & & & \\
\hline Frequency & 276 & 124 & & & \\
\hline \%age & 69 & 31 & & & \\
\hline Age & $15-25$ & $26-35$ & $36-45$ & 45> & \\
\hline Frequency & 88 & 220 & 48 & 44 & \\
\hline$\%$ age & 22 & 55 & 12 & 11 & \\
\hline Province & Baluchistan & Punjab & N.W.F.P & Sindh & \\
\hline Frequency & 12 & 340 & 44 & 4 & \\
\hline$\%$ age & 3 & 85 & 11 & 1 & \\
\hline Education & Under matric & Matric & Under graduate & Graduate & Post graduate \\
\hline Frequency & 8 & 20 & 44 & 148 & 180 \\
\hline$\%$ age & 2 & 5 & 11 & 37 & 45 \\
\hline Income & $>10,000$ & $10,000-20,000$ & $20,000-30,000$ & $30,000-40,000$ & $40,000>$ \\
\hline Frequency & 20 & 48 & 140 & 60 & 132 \\
\hline$\%$ age & 5 & 12 & 35 & 15 & 33 \\
\hline Income Source & Salary & Rent of property & Investment & Foreign remitta & \\
\hline Frequency & 252 & 56 & 20 & 72 & \\
\hline$\%$ age & 63 & 14 & 5 & 18 & \\
\hline Work Status & Retired & Govt. employed & Self employed & & \\
\hline Frequency & 16 & 264 & 120 & & \\
\hline$\%$ age & 4 & 66 & 30 & & \\
\hline Marital Status & Single & Married & & & \\
\hline Frequency & 204 & 196 & & & \\
\hline$\%$ age & 51 & 49 & & & \\
\hline Saving Preferences & $1-10 \%$ & $11-20 \%$ & $21-30 \%$ & $31-40 \%$ & $40 \%>$ \\
\hline Frequency & 100 & 132 & 72 & 68 & 28 \\
\hline
\end{tabular}


Gender Differences in Saving Behavior and its Determinants (Evidence from Punjab, Pakistan)

\begin{tabular}{|c|c|c|c|c|c|}
\hline \% age & 25 & 33 & 18 & 17 & 7 \\
\hline Own Home & Yes & No & & & \\
\hline Frequency & 332 & 68 & & & \\
\hline$\%$ age & 83 & 17 & & & \\
\hline Risk Tolerance Level & Low & Average & High & & \\
\hline Frequency & 136 & 220 & 44 & & \\
\hline \%age & 34 & 55 & 11 & & \\
\hline Saving & Short term & Medium tem & Long term & & \\
\hline Frequency & 188 & 112 & 100 & & \\
\hline$\%$ age & 47 & 28 & 25 & & \\
\hline Household Expense & $1-10 \%$ & $11-20 \%$ & $21-30 \%$ & $31-40 \%$ & $40 \%>$ \\
\hline Frequency & 32 & 40 & 148 & 128 & 52 \\
\hline$\%$ age & 8 & 10 & 37 & 32 & 13 \\
\hline Educational Expenses & $1-10 \%$ & $11-20 \%$ & $21-30 \%$ & $31-40 \%$ & $40 \%>$ \\
\hline Frequency & 192 & 164 & 36 & 4 & 4 \\
\hline$\%$ age & 48 & 41 & 9 & 1 & 1 \\
\hline Medical Expenses & $1-10 \%$ & $11-20 \%$ & $21-30 \%$ & $31-40 \%$ & \\
\hline Frequency & 284 & 100 & 12 & 4 & \\
\hline$\%$ age & 71 & 25 & 3 & 1 & \\
\hline $\begin{array}{l}\text { Miscellaneous } \\
\text { Expense }\end{array}$ & $1-10 \%$ & $11-20 \%$ & $21-30 \%$ & $31-40 \%$ & $40 \%>$ \\
\hline Frequency & 92 & 136 & 144 & 24 & 4 \\
\hline$\%$ age & 23 & 34 & 36 & 6 & 1 \\
\hline
\end{tabular}

Table 1.2 Characteristic of Male Respondents

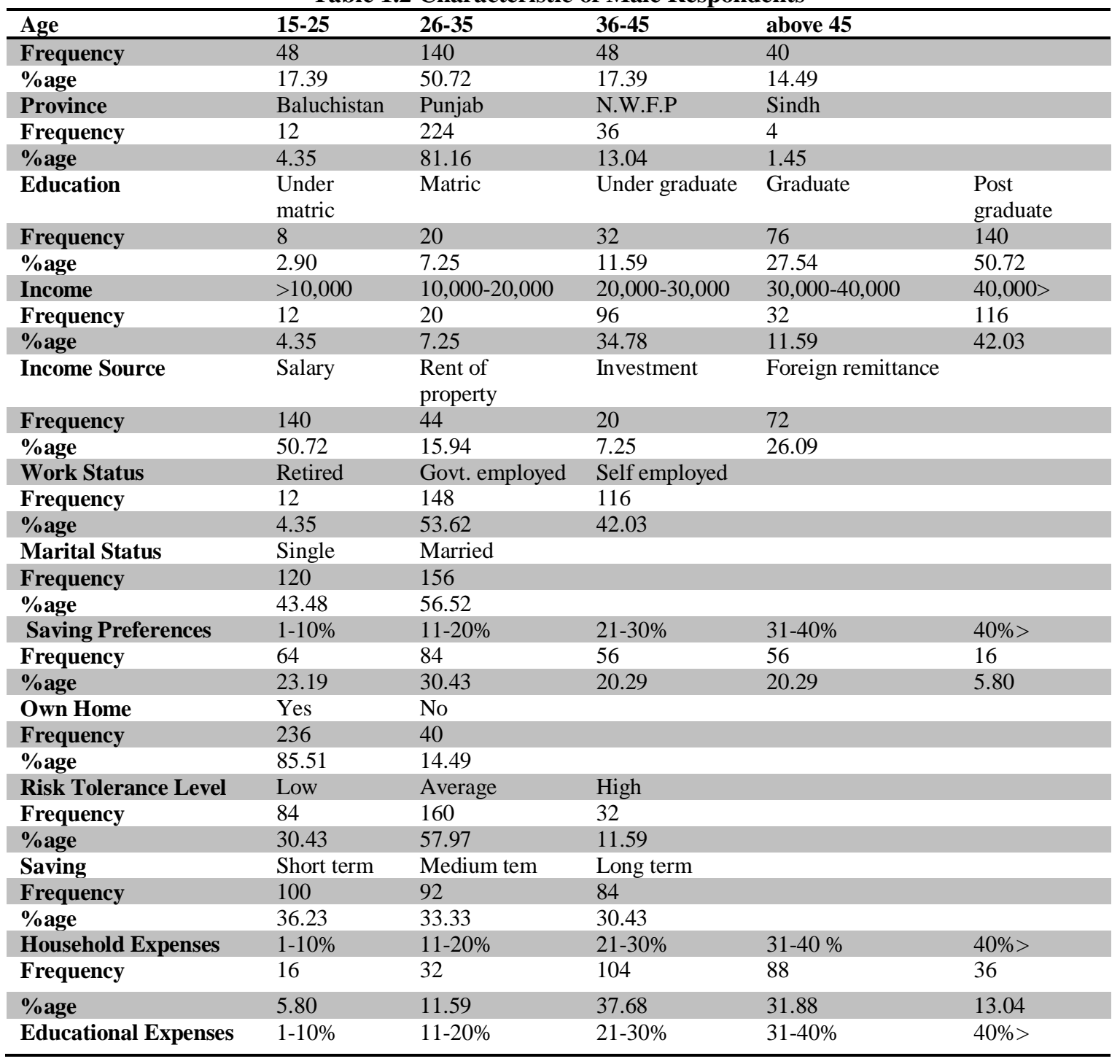


Gender Differences in Saving Behavior and its Determinants (Evidence from Punjab, Pakistan)

\begin{tabular}{|c|c|c|c|c|c|c|c|c|}
\hline Frequency & 140 & \multicolumn{2}{|c|}{112} & \multicolumn{2}{|l|}{16} & 4 & \multicolumn{2}{|c|}{4} \\
\hline$\%$ age & 50.72 & \multicolumn{2}{|l|}{40.58} & \multicolumn{2}{|l|}{5.80} & 1.45 & \multicolumn{2}{|c|}{1.45} \\
\hline Medical Expenses & $1-10 \%$ & \multicolumn{2}{|c|}{$11-20 \%$} & \multicolumn{2}{|c|}{$21-30 \%$} & \multicolumn{3}{|l|}{$31-40 \%$} \\
\hline Frequency & 184 & \multicolumn{2}{|c|}{84} & \multicolumn{2}{|c|}{4} & \multicolumn{3}{|l|}{4} \\
\hline$\%$ age & 66.67 & \multicolumn{2}{|c|}{30.43} & \multicolumn{2}{|l|}{1.45} & \multicolumn{3}{|l|}{1.45} \\
\hline Miscellaneous Expense & $1-10 \%$ & \multicolumn{2}{|c|}{$11-20 \%$} & \multicolumn{2}{|c|}{$21-30 \%$} & \multicolumn{3}{|l|}{$31-40 \%$} \\
\hline Frequency & 64 & 92 & & 104 & & 16 & & \\
\hline \%age & 23.19 & 33.33 & & 37.68 & & 5.80 & & \\
\hline Age & $15-25$ & & $26-35$ & & above 45 & & & \\
\hline Frequency & 40 & & 80 & & 4 & & & \\
\hline$\%$ age & 32.26 & & 64.52 & & 3.23 & & & \\
\hline Province & Punjab & & N.W.F.P & & & & & \\
\hline Frequency & 116 & & 8 & & & & & \\
\hline \%age & 93.55 & & 6.45 & & & & & \\
\hline Education & Under graduate & & Graduate & & Post graduat & & & \\
\hline Frequency & 12 & & 72 & & 40 & & & \\
\hline$\%$ age & 9.68 & & 58.06 & & 32.26 & & & \\
\hline Income & $>10,000$ & & $10,000-20,000$ & & $20,000-30,0$ & 000 & $30,000-40,000$ & $40,000>$ \\
\hline Frequency & 8 & & 28 & & 44 & & 28 & 16 \\
\hline$\%$ age & 6.45 & & 22.58 & & 35.48 & & 22.58 & 12.90 \\
\hline Income Source & Salary & & Rent of proper & & & & & \\
\hline Frequency & 112 & & 12 & & & & & \\
\hline$\%$ age & 90.32 & & 9.68 & & & & & \\
\hline Work Status & Retired & & Govt employec & & Self employ & yed & & \\
\hline Frequency & 4 & & 116 & & 4 & & & \\
\hline$\%$ age & 3.23 & & 93.55 & & 3.23 & & & \\
\hline Marital Status & Single & & Married & & & & & \\
\hline Frequency & 84 & & 40 & & & & & \\
\hline$\%$ age & 67.74 & & 32.26 & & & & & \\
\hline Saving Preferences & $1-10 \%$ & & $11-20 \%$ & & $21-30 \%$ & & $31-40 \%$ & $40 \%>$ \\
\hline Frequency & 36 & & 48 & & 16 & & 12 & 12 \\
\hline$\%$ age & 29.03 & & 38.71 & & 12.90 & & 9.68 & 9.68 \\
\hline Own Home & Yes & & No & & & & & \\
\hline Frequency & 96 & & 28 & & & & & \\
\hline$\%$ age & 77.42 & & 22.58 & & & & & \\
\hline Risk Tolerance Level & Low & & Average & & High & & & \\
\hline Frequency & 52 & & 60 & & 12 & & & \\
\hline$\%$ age & 41.94 & & 48.39 & & 9.68 & & & \\
\hline Saving & Short term & & Medium term & & Long term & & & \\
\hline Frequency & 88 & & 20 & & 16 & & & \\
\hline$\%$ age & 71 & & 16.1 & & 12.9 & & & \\
\hline Household Expense & $1-10 \%$ & & $11-20 \%$ & & $21-30 \%$ & & $31-40 \%$ & $40 \%>$ \\
\hline Frequency & 16 & & 8 & & 44 & & 40 & 16 \\
\hline$\%$ age & 12.90 & & 6.45 & & 35.48 & & 32.26 & 12.90 \\
\hline Educational Expenses & $1-10 \%$ & & $11-20 \%$ & & $21-30 \%$ & & & \\
\hline Frequency & 52 & & 52 & & 20 & & & \\
\hline$\%$ age & 41.94 & & 41.94 & & 16.13 & & & \\
\hline Medical Expenses & $1-10 \%$ & & $11-20 \%$ & & $21-30 \%$ & & & \\
\hline Frequency & 100 & & 16 & & 8 & & & \\
\hline$\%$ age & 80.65 & & 12.90 & & 6.45 & & & \\
\hline Miscellaneous Expense & $1-10 \%$ & & $11-20 \%$ & & $21-30 \%$ & & $31-40 \%$ & $40 \%>$ \\
\hline Frequency & 28 & & 44 & & 40 & & 8 & 4 \\
\hline$\%$ age & 22.58 & & 35.48 & & 32.26 & & 6.45 & 3.23 \\
\hline
\end{tabular}

Table 1.3 Characteristic of Female Respondents 
Table 1.4 by Univariate Gender Differences in Model

\begin{tabular}{|c|c|c|c|c|c|}
\hline Saving behavior & Short term & Medium term & Long term & & \\
\hline$\chi^{2}$ & 0.766 & 46.286 & 46.24 & & \\
\hline $\mathbf{p}$ & 0.381 & $.000 * * *$ & $.000 * * *$ & & \\
\hline Saving preferences & $1-10 \%$ & $11-20 \%$ & $21-30 \%$ & $31-40 \%$ & $40 \%>$ \\
\hline$\chi^{2}$ & 7.84 & 9.818 & 22.222 & 28.471 & 0.571 \\
\hline $\mathbf{p}$ & $0.005 *$ & $0.002 * *$ & $.000 * * *$ & $.000 * * *$ & 0.45 \\
\hline Age & $15-25$ & $26-35$ & $45>$ & & \\
\hline$\chi^{2}$ & 0.727 & 16.364 & 29.455 & & \\
\hline $\mathbf{p}$ & 0.394 & $.000 * * *$ & $.000 * * *$ & & \\
\hline Province & Punjab & N.W.F.P & & & \\
\hline$\chi^{2}$ & 34.306 & 17.818 & & & \\
\hline $\mathbf{p}$ & $.000 * * *$ & $.000 * * *$ & & & \\
\hline Education & $\begin{array}{l}\text { Under } \\
\text { graduate }\end{array}$ & Graduate & $\begin{array}{l}\text { Post } \\
\text { graduate }\end{array}$ & & \\
\hline$\chi^{2}$ & 9.091 & 0.108 & 55.556 & & \\
\hline $\mathbf{p}$ & $0.003 * *$ & 0.742 & $.000 * * *$ & & \\
\hline Income & $10,000<$ & $10,000-20,000$ & $\begin{array}{l}20,000- \\
30,000\end{array}$ & $\begin{array}{l}30,000- \\
40,000\end{array}$ & $40,000>$ \\
\hline$\chi^{2}$ & 0.8 & 1.333 & 19.314 & 0.267 & 75.758 \\
\hline $\mathbf{p}$ & 0.371 & 0.248 & $.000 * * *$ & 0.606 & $.000 * * *$ \\
\hline Income source & Salary & $\begin{array}{l}\text { Rent of } \\
\text { property }\end{array}$ & & & \\
\hline$\chi^{2}$ & 3.111 & 18.268 & & & \\
\hline $\mathbf{p}$ & 0.078 & $.000 * * *$ & & & \\
\hline Work Status & Retired & Govt employed & $\begin{array}{l}\text { Self } \\
\text { employed }\end{array}$ & & \\
\hline$\chi^{2}$ & 4 & 3.879 & 1.045 & & \\
\hline $\mathbf{p}$ & $0.046 *$ & $0.049 *$ & $.000 * * *$ & & \\
\hline Marital Status & Single & Married & & & \\
\hline$\chi^{2}$ & 6.353 & 68.653 & & & \\
\hline $\mathbf{p}$ & $0.012 *$ & $.000 * * *$ & & & \\
\hline Own Home & Yes & No & & & \\
\hline$\chi^{2}$ & 59.036 & 2.118 & & & \\
\hline $\mathbf{p}$ & $.000 * * *$ & 0.146 & & & \\
\hline Risk Tolerance Level & Low & Average & High & & \\
\hline$\chi^{2}$ & 7.529 & 45.455 & 9.091 & & \\
\hline $\mathbf{p}$ & $0.006 * *$ & $.000 * * *$ & $0.003 * *$ & & \\
\hline Household Expense & $0-10 \%$ & $11-20 \%$ & $21-30 \%$ & $31-40 \%$ & $40 \%>$ \\
\hline$\chi^{2}$ & 0 & 14.4 & 24.324 & 18 & 7.692 \\
\hline $\mathbf{p}$ & 1 & $.000 * * *$ & $.000 * * *$ & $.000 * * *$ & $0.006 * *$ \\
\hline Educational Expenses & $0-10 \%$ & $11-20 \%$ & $21-30 \%$ & & \\
\hline$\chi^{2}$ & 40.333 & 21.951 & 0.444 & & \\
\hline $\mathbf{p}$ & $.000 * * *$ & $.000 * * *$ & 0.505 & & \\
\hline Medical Expenses & $0-10 \%$ & $11-20 \%$ & $21-30 \%$ & & \\
\hline$\chi^{2}$ & 24.845 & 46.24 & 1.333 & & \\
\hline $\mathbf{p}$ & $.000 * * *$ & $.000 * * *$ & 0.248 & & \\
\hline $\begin{array}{l}\text { Miscellaneous } \\
\text { Expense }\end{array}$ & $0-10 \%$ & $11-20 \%$ & $21-30 \%$ & $31-40 \%$ & \\
\hline$\chi^{2}$ & 14.087 & 16.941 & 28.444 & 2.667 & \\
\hline$\hat{p}$ & $.000 * * *$ & $.000 * * *$ & $.000 * * *$ & 0.102 & \\
\hline
\end{tabular}

$* p<.05 . * * p<.01 . * * * p<.001$. 
Saving behavior is very much different on the basis of gender as $71 \%$ females save for short term needs while only $36 \%$ males save for short term needs and males also saved almost equal proportion for medium and long term needs. Spending pattern of both genders for household purpose is almost same but there is a little difference in terms of educational expenses as $92 \%$ of males spends $1-20 \%$ of their income for education while $82 \%$ females show same pattern of spending. On the other hand females spend for medical expenses as $80 \%$ spend only $10 \%$ of their income as compare to $60 \%$ males expressing same behavior.

Table 1.4 contains the result of nonparametric test applied to check the differences exist in variables of study and the saving behaviors among males and females. According to result, most of significant differences exist among males and females. On the hand, there are no significant differences among both genders in some characteristics of variables. There are no significant differences of males and females having Graduate education and age of 15-25 years old. Both genders also have no difference in educational and medical expenses that lies in the range of $21-30 \%$ of consumption of income while there are also no significant difference in household expenses and miscellaneous expenses in the range of $1-10 \%$ and $31-40 \%$ consumption of income. In all remaining characteristics, both gender are significantly different from each expect in income level of less than 10,000 to 20,000, source of income of salary and in short term saving behavior. The main focus of this nonparametric test was to check the differences exist in saving behavior among males and females.

According to results, both genders have significantly different behaviors in the terms of medium and long term savings as the univariate estimates for short term and long term saving are respectively 46.286 and 46.24 with significant level of $(p<.001$.). The results of short term saving behavior is supporting the result of Patti J. Fisher (2010) as its result was $\chi 2=21.746$.

\subsection{Linear Regression}

Linear regression analysis was applied to check the gender differences in determinants of saving among males and females. Correlation of all the variables of study was measured and the detail of correlation analysis is available in appendix. Both tables of correlation are showing that values of correlation are less than 0.40 . Theses results of correlation are confirmed with the results of Patti J. Fisher (2010). So, all the independent variables are used collectively to apply regression analysis.

\begin{tabular}{lcccc}
\hline Gender & R & R Square & $\begin{array}{c}\text { Adjusted R } \\
\text { Square }\end{array}$ & Std. Error \\
\hline Male & 0.72 & 0.52 & 0.495 & 0.57999 \\
Female & 0.827 & 0.685 & 0.644 & 0.42412 \\
\hline
\end{tabular}

Table 1.5 Model Summary

The results given in table 1.5 shows males saving behavior is effected up to $52 \%$ (as regression estimates of 0.52 with $\mathrm{p}<.001$ ) by the determinants of saving behavior selected for study while females are effected up to $68 \%$ ( as regression estimates of 0.685 with $\mathrm{p}<.001$ ).Demographic characteristics of age and province affect the male positively while as the coefficient values for age and province are 0.073 and 0.125 respectively while same determinants are affecting the saving behavior negatively as the coefficient values of age and province are -0.062 and -0.287 respectively. Income source, marital status and educational expenses have negative impact for males as the coefficient values for male of these determinants are $-0.019,-0.124$ and 0.201 are respectively while females are effecting by these determinants positively as the coefficient values for Income source, marital status and educational expenses are $0.283,0.751$ and 0.16 . Household expenses and income have positive impact for males and negative impact for females on saving behavior. Results of linear regression show that both males and females are different in all determinants of saving excluding education, work status, own home and risk tolerance level as the determinants of saving.

\begin{tabular}{lcr}
\hline \multicolumn{3}{c}{ Coefficients } \\
\hline & Model & \\
\hline Age & Male & \multicolumn{1}{c}{ Model 2 } \\
Province & 0.073 & Female \\
Education & $0.125 * *$ & -0.062 \\
Income & $-0.221 * * *$ & $-0.287 * * *$ \\
Income Source & 0.099 & $-0.4 * * *$ \\
Work Status & -0.019 & $-0.604 * * *$ \\
Marital Status & 0.008 & $0.283 * *$ \\
Saving preferences & $-0.124 * *$ & $0.355^{* *}$ \\
\hline
\end{tabular}




\begin{tabular}{lrr}
\hline Own Home & -0.004 & $-0.56 * * *$ \\
Risk Tolerance Level & $0.169 * * *$ & $0.786 * * *$ \\
Household Expense & $0.257 * * *$ & $-0.467 * * *$ \\
Educational Expenses & $-0.201 * * *$ & $0.16 * *$ \\
Medical Expenses & -0.016 & -0.029 \\
\hline Miscellaneous Expense & $-0.172 * *$ & -0.118 \\
\hline
\end{tabular}

Table 1.6 Effects of Determinants of Saving by Gender

$* p<.05 . * * p<.01 . * * * p<.001$.

\section{Conclusion}

The results of study show that males and females have significantly different preferences. According to descriptive analysis females are more likely to save for short term as compare to males while males are likely to save almost for short, medium and long term purposes also. Education and income level of males in Pakistan is higher than females while the most of females are salaried and government employed. On the hand males are dependent on salary and foreign remittance with having work status of government and self employed. In term of percentage saving, males save more as compare to females while they have more risk aversion behavior than males. Consumption patterns of both genders are as males spend more for house hold purpose while females spend on miscellaneous expense.

Males and females have significant differences in determinants of saving behavior. Males of higher age save more as compare to males while females of Punjab have low saving behavior than males. Males with higher level of income save more while females do not save more by increasing their income level while married males save less as compare to females. Most important conclusion regarding the impact of consumption pattern is that when males have to spend more for household and less for miscellaneous expense than they will save more as compare to females who will save less in same case. The saving behavior of males is negatively related with females because males spend more for education as compare to females and when they have to spend on education females save more than males.

The private manufacturing industries are spending millions and billions of dollars in promoting and advertising their goods every year to convince the customers to spend on products more. But, if the spending level is high and saving level is too low then individuals with higher income may be asked to pay higher taxes to help those individuals have low income for their departures. It is also important in this way that, some people who have low income and low education, they save very low amount of their income and save that income through different ways other than, highly educated and highly income individuals. So, it must be important to target these low income and low educated people and develop policies according to their needs. These policies and programs can provide guidance to poor's to increase their income level.

Our study shows that men save more than females and women spend more than males, this information can be beneficial for financial intermediaries, companies and for government in making polices for this area. Here men save more but little knowledge for investment, investment firms can focus on this area and use the saving money of the people for investment. People spend for health facilities and education government can improve health facilities by devising better policies so that genders can reduce their medical expense and improve their saving levels by working in better environment. Education should be promoted by government by increasing budgets for education. There must be free schooling and also scholarship to provide opportunity to individuals to spend less on education. Education facility must be the responsibility of state.

Further research on saving behavior can be conducted on the other big cities of Punjab and other provinces. Uncertainty and risk have significant impact on saving behavior, so upcoming research studies could be on uncertainty and saving behavior. There are many topics which can be analyzed with reference to saving behavior of individuals as saving behavior of can be checked in terms of cultural differences and economic conditions of countries.

\section{References}

[1] Bajtelsmit, V. L., \& Bernasek, A. (1996). Why do women invest differently than men? Financial Counseling and Planning, 7, 1-10.

[2] Bajtelsmit, V. L., Bernasek, A., \& Jianakopolos, N. A. (1996). Gender effects in pension investment allocation decisions. Center for Pension and Retirement Research, 145-156.

[3] Patti J. Fisher (2010). Gender Differences in Personal Saving Behaviors. Financial Counseling and Planning,8, 14-24.

[4] O. S. Mitchell, \& M. M. Twinney (Eds.), Positioning pensions for the twenty-first century. Philadelphia: University of Pennsylvania Press.

[5] Embrey, L., \& Fox, J. (1997). Gender differences in the investment decision-making process. Financial Counseling and Planning, $8(2), 33-40$

[6] Sunden, A. E., \& Surrette, B. J. (1998). Gender differences in the allocation of assets in retirement savings plans. American Economic Review, 88, 207-211.

[7] Agnew, J. (2005). Do behavioral biases vary across individuals? Evidence from individual level 401(k) data. Journal of Financial and Quantitative Finance, 41, 939-962. 
[8] Schmidt, L., \& Sevak, P. (2006). Gender, marriage, and asset accumulation in the United States. Feminist Economics, 12(1), 139166.

[9] V. G. Perry and M. D. Morris, "Who Is in Control? The Role of Self Perception, Knowledge, and Income in Explaining Consumer Financial Behavior," J. Consumer Aff., vol. 39, pp. 299-313, 2005.

[10] J. Y. Rha, C. P. Montalto and S. D. Hanna, "The effect of self-control mechanisms on household saving behavior," Financial Counseling and Planning, vol. 17, pp. 3-16, 2006.

[11] Kelley, A. C and Williamson, J. W., 1968, "Household Saving Behavior in Developing Countries: The Indonesia Case". Economic Development and Cultural Change. Vol. 16, No.3.'

[12] Khan, A. H., 1988, "Financial Repression Development and Structure of Saving in Pakistan". The Pakistan Development Review, 27(4): $702-713$.

[13] Burney, Nadeem and Ashfaque H. Khan, 1992, "Socio-economic Characteristics and Household Savings". An Analysis of Household Saving Behaviour in Pakistan. The Pakistan Development Review.3 (1). 31 - 48

[14] Croson, R., \& Gneezy, U. (2004). Gender differences in preferences. Journal of Economic Literature, 47, 448-474.

[15 ] Zhong, L. X., \& Xiao, J. J. (1995). Determinants of family bond and stock holdings. Financial Counseling and Planning, 6, $107-114$.

[16] Graham, J. F., Stendardi, E. J., Myers, J. K., \& Graham, M. J. (2002). Gender differences in investment strategies: An information processing perspective. The International Journal of Bank Marketing, 20, 17-26.

[17] Lupton, J., \& Smith, J. P. (2003). Marriage, assets, and savings. In S. Grossbard Shechtman (Ed.), Marriage and the Economy: Theory and Evidence from Industrialized Societies (pp. 129-152). Cambridge, England: Cambridge University Press.

[18] DeVaney, S., \& Su, Y. (1997). Factors predicting the most important source of retirement income. Compensation \& Working Conditions, 2, 25-51.

[19] Masters, R., \& Meier, R. (1988). Sex differences in risk taking propensity of entrepreneurs. Journal of Small Business Management, 26(1), 31-35.

[19] U.S. Bureau of the Census. (2007). Current Population Reports. Washington, DC.

[20] Blau, F. D., \& Kahn, L. M. (1997). Swimming upstream: Trends in the gender wage differential in the 1980s. Journal of Labor Economics, 15(1), 1-42.

[21] Lusardi, A., \& Mitchell, L. (2007). Financial literacy and retirement preparedness: Evidence and implications for financial education. Business Economics, 42(1), 35-44.

[22] Sung, J., \& Hanna, S. (1996). Factors related to risk tolerance. Financial Counseling and Planning, 7, 11-20.

[23] Gottschalck, A. O. (2008). Net worth and the assets of households: 2002. (Current Population Reports P70- 115). Washington, DC: U.S. Census Bureau.

[24] Moore, Q., \& Shierholz, H. (2004). Why did the convergence of male and female wages slow during the 1990s? Unpublished manuscript. Michigan Retirement Research Center, University of Michigan, Ann Arbor, MI.

[25] O'Neill, J. (2003). The gender gap in wages, circa 2000. American Economic Review, 93(2), 309-314.

[26] Berger, E., \& Denton, M. (2004). The interplay between women's work histories and financial planning for later life. Canadian Journal on Aging, 23, 99-113.

[27] Becker, G. (1975). Human Capital. New York: National Bureau of Economic Research.

[28] Sierminska, E. M., Frick, J. R., \& Grabka, M. M. (2008). Examining the gender wealth gap in Germany. DIW Discussion Paper \#806. Berlin.

[29] Brinig, M. F. (1995). Does mediation systematically disadvantage women? Journal of Women and the Law, 2, 1-34.

[30] Lewis, A., Webley, P., \& Furnham, A. (1995). The new economic mind. The social psychology of economic behaviour. Hemel Hempstead: Harvester Wheatsheaf.

[31] Wärneryd, K. E. (1999). The psychology of saving. A study of economic psychology. Cheltenham: Edward ElgarPublishing.

\section{Appendix}

\begin{tabular}{|c|c|c|c|c|c|c|c|c|}
\hline \multicolumn{9}{|c|}{ Correlations } \\
\hline & Gender & Age & Province & Education & Income & $\begin{array}{l}\text { Income } \\
\text { Source }\end{array}$ & $\begin{array}{l}\text { Work } \\
\text { Status }\end{array}$ & $\begin{array}{l}\text { Marital } \\
\text { Status }\end{array}$ \\
\hline Gender & 1 & $-.290^{* *}$ & -0.085 & 0.032 & $-.257^{* * *}$ & $-.394^{* * *}$ & $-.334^{* * *}$ & $-.224^{* *}$ \\
\hline Age & $-.290^{* *}$ & 1 & 0.022 & -0.05 & $.285^{* *}$ & $.193^{* *}$ & $.107^{*}$ & $.483^{* *}$ \\
\hline Province & -0.085 & 0.022 & 1 & $.103^{*}$ & $.105^{*}$ & $.287^{* *}$ & $.249^{* *}$ & 0.09 \\
\hline Education & 0.032 & -0.05 & $.103^{*}$ & 1 & 0.047 & $-.190^{* *}$ & -0.094 & -0.017 \\
\hline Income & $-.257^{* * *}$ & $.285^{* *}$ & $.105^{*}$ & 0.047 & 1 & $.415^{* *}$ & $.441^{* *}$ & $.418^{* *}$ \\
\hline $\begin{array}{l}\text { Income } \\
\text { Source }\end{array}$ & $-.394^{* *}$ & $.193^{* *}$ & $.287^{* *}$ & $-.190^{* *}$ & $.415^{* *}$ & 1 & $.753^{* *}$ & 0.065 \\
\hline $\begin{array}{l}\text { Work } \\
\text { Status }\end{array}$ & $-.334^{* *}$ & $.107^{*}$ & $.249^{* *}$ & -0.094 & $.441^{\text {** }}$ & $.753^{\text {*** }}$ & 1 & 0.087 \\
\hline $\begin{array}{l}\text { Marital } \\
\text { Status }\end{array}$ & $-.224^{* *}$ & $.483^{* *}$ & 0.09 & -0.017 & $.418^{* *}$ & 0.065 & 0.087 & 1 \\
\hline
\end{tabular}


Gender Differences in Saving Behavior and its Determinants (Evidence from Punjab, Pakistan)

\begin{tabular}{|c|c|c|c|c|c|c|c|}
\hline \multicolumn{8}{|c|}{ Correlations } \\
\hline & $\begin{array}{c}\text { Saving } \\
\text { preferen } \\
\text { ces }\end{array}$ & $\begin{array}{c}\text { Own } \\
\text { Home }\end{array}$ & $\begin{array}{c}\text { Risk } \\
\text { Tolerance } \\
\text { Level }\end{array}$ & Saving & $\begin{array}{l}\text { Household } \\
\text { Expense }\end{array}$ & $\begin{array}{l}\text { Educational } \\
\text { Expenses }\end{array}$ & $\begin{array}{c}\text { Medical } \\
\text { Expenses }\end{array}$ \\
\hline $\begin{array}{l}\text { Saving } \\
\text { preference }\end{array}$ & 1.00 & -0.33 & 0.13 & 0.45 & -0.07 & -0.19 & 0.20 \\
\hline Own Home & -0.33 & 1.00 & 0.12 & -0.11 & 0.04 & 0.10 & -0.13 \\
\hline $\begin{array}{l}\text { Risk } \\
\text { Tolerance } \\
\text { Level }\end{array}$ & 0.13 & 0.12 & 1.00 & 0.27 & 0.21 & -0.02 & 0.08 \\
\hline Saving & 0.45 & -0.11 & 0.27 & 1.00 & 0.18 & -0.17 & 0.16 \\
\hline $\begin{array}{l}\text { Household } \\
\text { Expense }\end{array}$ & -0.07 & 0.04 & 0.21 & 0.18 & 1.00 & 0.19 & 0.02 \\
\hline $\begin{array}{l}\text { Educational } \\
\text { Expenses }\end{array}$ & -0.19 & 0.10 & -0.02 & -0.17 & 0.19 & 1.00 & -0.03 \\
\hline $\begin{array}{l}\text { Medical } \\
\text { Expenses }\end{array}$ & 0.20 & -0.13 & 0.08 & 0.16 & 0.02 & -0.03 & 1.00 \\
\hline $\begin{array}{l}\text { Miscellaneo } \\
\text { us Expense }\end{array}$ & 0.16 & -0.28 & 0.04 & 0.03 & -0.07 & -0.38 & 0.08 \\
\hline
\end{tabular}

Model Summary

\begin{tabular}{|ll|r|r|r|r|}
\hline Gender & Model & \multicolumn{1}{|c|}{ R } & R Square & \multicolumn{1}{|c|}{$\begin{array}{c}\text { Adjusted R } \\
\text { Square }\end{array}$} & $\begin{array}{c}\text { Std. Error of the } \\
\text { Estimate }\end{array}$ \\
\hline male & 1 & $.721^{\mathrm{a}}$ & .520 & .495 & .57999 \\
\hline female & 1 & $.827^{\mathrm{b}}$ & .685 & .644 & .42412 \\
\hline
\end{tabular}

ANOVA ${ }^{c}$

\begin{tabular}{|lll|r|r|r|r|r|}
\hline Gender & Model & & Sum of Squares & df & Mean Square & F & Sig. \\
\hline male & 1 & Regression & 95.276 & 14 & 6.805 & 20.231 & $.000^{\mathrm{a}}$ \\
& & Residual & 87.797 & 261 & .336 & & \\
& Total & 183.072 & 275 & & & \\
\hline & & 42.587 & 14 & 3.042 & 16.911 & $.000^{\mathrm{b}}$ \\
& Regression & 19.606 & 109 & .180 & & \\
& Residual & 62.194 & 123 & & & \\
& Total & & & & & \\
\end{tabular}

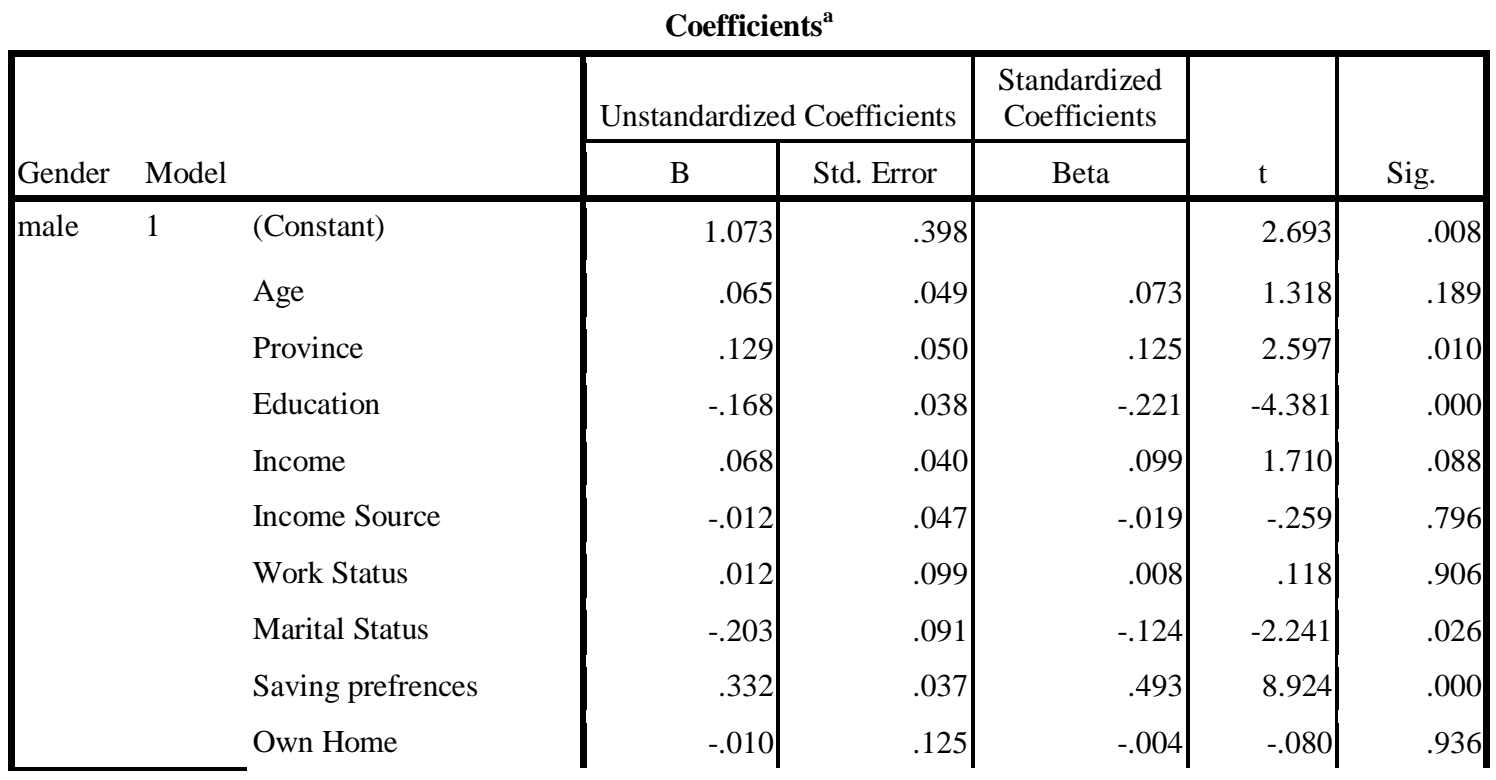




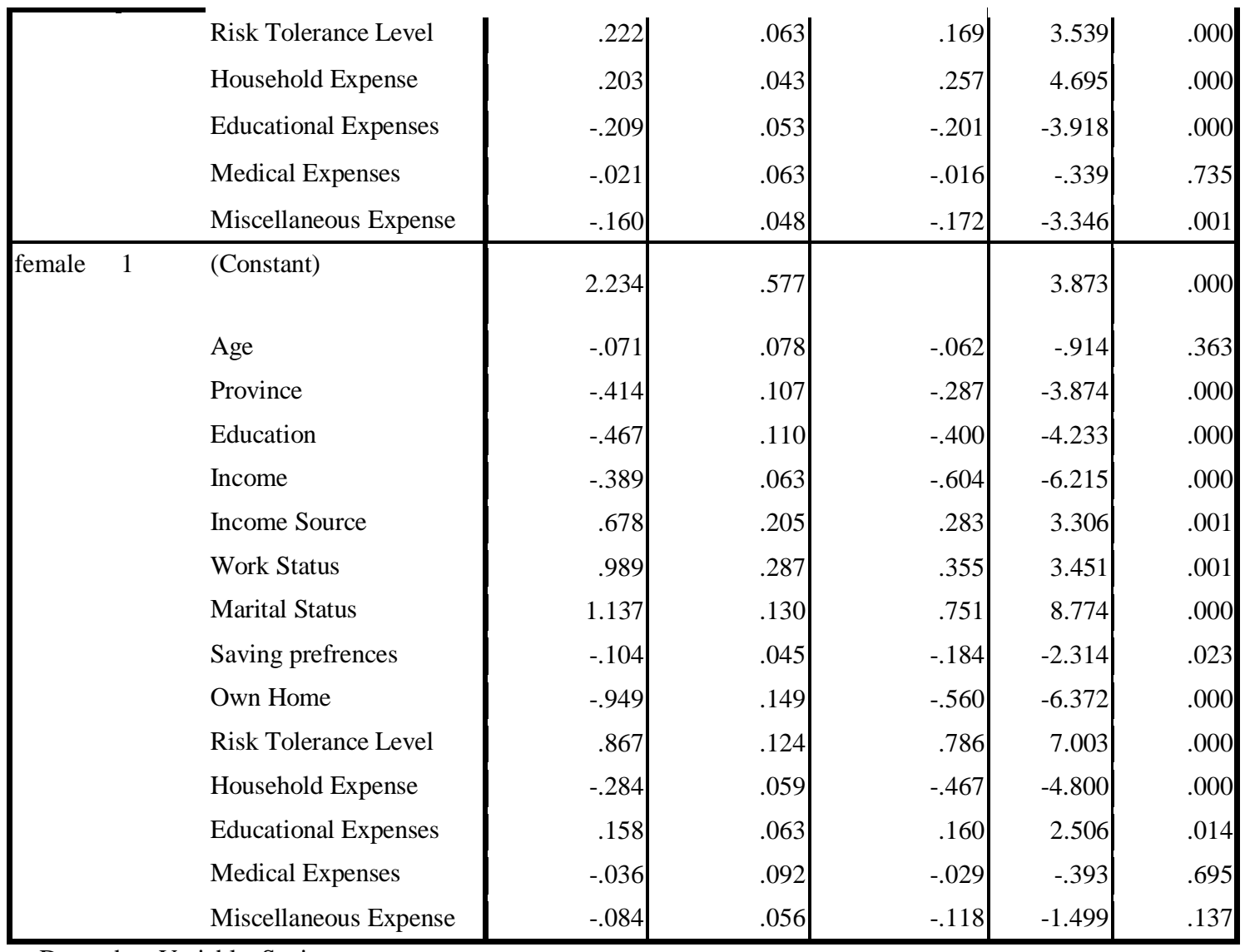

a. Dependent Variable: Saving 